\title{
Persepsi dan Perilaku Konsumen Bisnis terhadap Daging Sapi Beku, Studi Kasus: DKI Jakarta, Indonesia
}

\author{
Business Consumers' Perception and Behavior Towards Frozen Beef, Case Study: DKI Jakarta, Indonesia
}

\author{
A. Apriantini ${ }^{1 *}$, I. I. Arief ${ }^{1}$, L. Cyrilla ENSD ${ }^{1}$, S. Riyanto ${ }^{2}, \&$ R. Adiyoga ${ }^{1}$ \\ ${ }^{1}$ Departemen Ilmu produksi dan Teknologi Peternakan, Fakukultas Peternakan, IPB University, \\ ${ }^{2}$ Departemen Sains Komunikasi dan Pengembangan Masyarakat, Fakultas Ekologi Manusia, IPB University \\ Indonesia Jl. Lingkar Akademik, Kampus IPB Darmaga, 16680 Bogor \\ *Corresponding author: astariapriantini@yahoo.com \\ (Received 28-10-2020; Revised 19-11-2020; Accepted 21-12-2020)
}

\begin{abstract}
The perception and purchase behavior to frozen beef from 90 Business consumers in Jakarta, Indonesia were evaluated. Respondents were interviewed face-to-face by a structured questionnaire. The questionnaire was divided into three parts, first part about characteristic of respondents, second part about purchasing behavior, and the last part about respondents' perceptions toward frozen beef. Moreover, the relationship between perceptions and consumer characteristics of frozen beef was analyzed. Business consumers in the DKI Jakarta had a good perception of frozen beef. The aspect of product quality had the lowest score and price aspect had the highest score. Business scale had a significant relationship with consumer perceptions $(P<0.05)$. This result showed that the larger of the business scale cause the better perception of business consumers towards frozen beef. The amount of beef consumption per month had a significant relationship $(P<0.05)$ and in line with the level of business consumers' perceptions of frozen beef. This result showed a significant relationship between the level of consumer perception and the amount of beef consumption per month. the high beef consumption cause the better the consumer's perception of frozen beef. The increasing consumption indicates that the respondents had a good perception.
\end{abstract}

Keywords: business consumer, consumer perception, frozen beef, purchase behavior

\begin{abstract}
ABSTRAK
Penelitian ini bertujuan untuk menganalisis persepsi dan perilaku dalam pembelian daging sapi beku oleh pelaku usaha di DKI Jakarta. Responden berjumlah 90 konsumen bisnis. Penelitian ini dilakukan dengan cara interview langsung menggunakan kuesioner. Kuesioner terdiri atas tiga bagian yaitu karakteristik dari responden, perilaku konsumen dalam pembelian daging beku dan persepsi konsumen terhadap daging beku. Setelah itu, dianalisis hubungan antara persepsi dan karakteristik konsumen daging sapi beku. Konsumen bisnis di wilayah DKI Jakarta memiliki persepsi yang baik terhadap daging sapi beku. Aspek kualitas produk merupakan aspek dengan skor terendah dan aspek dengan skor tertinggi yaitu aspek harga. Skala usaha memiliki hubungan yang signifikan dan searah dengan persepsi konsumen $(\mathbf{P}<\mathbf{0 . 0 5})$. Hal ini menunjukkan bahwa semakin besar skala usaha maka semakin baik persepsi konsumen bisnis terhadap daging sapi beku. Jumlah konsumsi daging sapi per bulan memiliki hubungan yang signifikan $(\mathrm{P}<0.05)$ dan searah dengan tingkat persepsi konsumen bisnis terhadap daging sapi beku. Hal ini menunjukkan adanya hubungan yang berarti antara tingkat persepsi konsumen dengan jumlah konsumsi daging sapi per bulan. Hubungan yang searah menunjukkan bahwa semakin banyak konsumsi daging sapi maka akan semakin baik persepsi konsumen terhadap daging sapi beku. Konsumsi yang semakin meningkat menunjukkan bahwa responden memiliki persepsi yang baik.
\end{abstract}

Kata kunci: daging sapi beku, konsumen bisnis, persepsi konsumen, perilaku pembelian 


\section{PENDAHULUAN}

Subsektor peternakan merupakan salah satu subsektor yang berperan dalam pemenuhan gizi masyarakat, karena menghasilkan banyak komoditi pangan sumber protein hewani diataranya daging sapi, daging unggas, daging kambing, susu dan telur. Salah satu pangan asal ternak yang banyak dikonsumsi oleh masyarakat adalah daging sapi. Daging sapi memiliki kandungan gizi yang baik untuk manusia, khususnya zat gizi protein yang sangat dibutuhkan selama proses pertumbuhan dan perbaikan sel-sel tubuh yang rusak. Konsumen daging sapi meningkat seiring dengan bertambahnya jumlah penduduk dan meningkatnya kesadaran masyarakat untuk mengonsumsi pangan yang bergizi dan beragam. Namun, kebutuhan daging sapi di Indonesia masih belum bisa dipenuhi oleh produksi dalam negeri sehingga pemerintah membuat kebijakan impor daging sapi untuk memenuhi kebutuhan tersebut, khususnya untuk segmen pasar industri dan bisnis horeka (Bappenas 2015).

Daging sapi yang umumnya dijual di pasar tersedia dalam berbagai bentuk, yaitu daging sapi segar, daging sapi dingin, dan daging sapi beku. Daging beku adalah daging segar yang sudah mengalami proses pembekuan di dalam freezer dengan temperatur internal minimum $-18{ }^{\circ} \mathrm{C}$ (BSN 2008). Proses pembekuan dapat menghambat pertumbuhan mikroorganisme sehingga masa simpannya menjadi lebih lama dan penampilan daging beku yang sudah dithawing tidak jauh berbeda dengan daging sapi segar (Cassius 2017). Proses pembekuan tidak berpengaruh nyata pada kandungan nutrisi daging sapi beku, proses pembekuan menyebabkan peningkatan kandungan lemak dan protein serta berkurangnya kadar air pada suhu pembekuan yang lebih tinggi, sehingga dapat diketahui bahwa daging sapi beku memiliki kandungan gizi yang baik (Widiati 2008). Menurut Adam et al. (2010) dalam Cassius (2017), suhu pembekuan dibawah $-5^{\circ} \mathrm{C}$ akan menghambat perkembangan mikroba sehingga aman untuk disimpan lama.

Konsumen daging sapi terpusat di DKI Jakarta, Banten, dan Jawa Barat (Bappenas 2015). Konsumsi daging di wilayah DKI Jakarta direpresentasikan dengan pengeluaran per kapita per bulan untuk produk daging yang meningkat dari Rp 18630 pada tahun 2009 menjadi Rp 28144 pada tahun 2013 (BPS 2013). Konsumen terdiri atas dua jenis yaitu konsumen individu dan konsumen organisasi atau konsumen bisnis. Konsumen rumah tangga merupakan konsumen individu yang menghabiskan langsung suatu jasa atau mengolah lebih lanjut untuk dikonsumsi anggota keluarganya. Sedangkan untuk konsumen bisnis, merupakan konsumen yang membeli suatu produk untuk menjalankan seluruh kegiatan usahanya sehingga biasanya melakukan pembelian dalam jumlah banyak (Sumarwan 2014). Hal ini ditunjukan oleh data dari Bappenas (2015) yang menyatakan, konsumen organisasi atau konsumen bisnis seperti hotel, restoran, katering, supermarket, industri pengolahan besar, dan pasar tradisional membeli daging sapi dalam jumlah yang paling banyak, terutama daging sapi impor dalam bentuk daging beku.

Sebelum membeli suatu produk, konsumen akan melalui beberapa tahapan hingga akhirnya memutuskan untuk membeli atau tidak produk tersebut. Keputusan akhir pembelian dipengaruhi oleh berbagai faktor, diantaranya persepsi konsumen, karakteristik konsumen, serta atribut produk seperti harga, merek dan asal produk tersebut. Persepsi konsumen merupakan hasil dari pengolahan informasi, yang merupakan pandangan awal konsumen terhadap suatu produk. Persepsi yang baik akan mengantarkan konsumen untuk mengkonsumsi atau membeli suatu produk (Sumarwan 2014). Oleh karena itu analisis mengenai persepsi dan perilaku konsumen terhadap daging sapi beku sangat berguna untuk menentukan segmentasi pasar dan menetapkan strategi pemasaran yang tepat untuk daging sapi beku, khususnya di wilayah DKI Jakarta. Penelitian ini dipusatkan di wilayah DKI Jakarta dikarenakan DKI Jakarta merupakan barometer perdagangan sehingga pola konsumsi yang ada di DKI Jakarta dapat mempengaruhi pola konsumsi di wilayah lain di Indonesia.

Penelitian ini bertujuan untuk mengidentifikasi karakteristik dan menganalisis persepsi konsumen bisnis terhadap daging sapi beku, menganalisis hubungan antara persepsi dan karakteristik konsumen daging sapi beku, serta menganalisis perilaku konsumen bisnis dalam proses pengambilan keputusan untuk membeli daging sapi beku di wilayah DKI Jakarta.

Penelitian ini dilaksanakan di wilayah DKI Jakarta meliputi proses wawancara terhadap responden yang terdiri atas usaha hotel, restoran, katering, swalayan, supplier dan kios daging di pasar tradisional. Penelitian ini ditujukan untuk mengidentifikasi persepsi, karakteristik, dan perilaku dalam proses pengambilan keputusan pembelian konsumen pelaku usaha terhadap daging sapi beku.

\section{MATERI DAN METODE}

\section{Waktu dan Lokasi Penelitian}

Penelitian ini dilaksanakan pada bulan Maret hingga September 2018 di wilayah DKI Jakarta terhadap usaha hotel, restoran, katering, swalayan, supplier daging sapi beku, dan kios daging di pasar tradisional.

\section{Materi}

Materi yang digunakan pada penelitian ini adalah kuisioner penelitian yang terdiri atas pertanyaan tertutup dan terbuka. Kuisioner terbagi menjadi 3 bagian yang berisi karakteristik responden, perilaku pembelian, dan persepsi responden terhadap daging sapi beku. Pengukuran persepsi responden menggunakan skala Likert dengan 4 skala yang dikategorikan menjadi $\mathrm{STS}=$ Sangat Tidak Setuju, TS= Tidak Setuju, $S=$ Setuju, dan $S S=$ Sangat Setuju.

\section{Prosedur}

\section{Penentuan Sampel}

Sampel yang digunakan pada penelitian ini berjumlah 90 sampel pelaku usaha terdiri atas 8 usaha katering, 11 usaha swalayan, 6 hotel, 7 usaha supplier daging sapi beku, 18 kios daging di pasar tradisional dan 40 restoran. Responden dipilih dengan cara non probability sampling menggunakan teknik purposive sampling, yaitu responden dipilih berdasarkan pertimbangan tertentu (Sugiyono 2015). Responden yang dipilih merupakan 
usaha yang melakukan pembelian atau pernah membeli daging sapi beku untuk dijual dalam bentuk bahan pangan segar atau diolah menjadi menu utama.

\section{Pengumpulan Data}

Data yang digunakan dalam penelitian ini terdiri atas data primer dan data sekunder, baik kualitatif maupun kuantitatif. Data primer diperoleh dari konsumen melalui wawancara langsung dan melalui pengisian kuesioner sebagai panduan, sedangkan data sekunder diperoleh dari dinas-dinas dan instansi terkait, seperti Badan Pusat Statistik DKI Jakarta, Dinas Perdagangan dan Perindustrian serta referensi kepustakaan lainnya.

\section{Analisis Data}

Analisis yang digunakan dalam penelitian ini adalah analisis deskriptif untuk mendeskripsikan persepsi, karakteristik konsumen serta proses pengambilan keputusan pembelian. Proses pengambilan keputusan pembelian didasarkan pada Kotler (2005) yaitu pengenalan kebutuhan, pencarian informasi, evaluasi alternatif, keputusan pembelian, dan perilaku setelah pembelian.

Data selanjutnya ditampilkan dalam bentuk frekuensi, rataan, persentase, dan rataan skor. Hubungan antara persepsi dan karakteristik konsumen bisnis dianalisis menggunakan uji korelasi Rank Spearman (Silalahi 2012).

\section{Uji Validitas dan Reliabilitas}

Uji validitas dilakukan untuk mengetahui apakah kuisioner mampu mengukur apa yang ingin diukur. Uji validitas dikatakan valid jika memiliki dukungan yang kuat terhadap skor total. Korelasi dari item-item kuisioner harus kuat dan peluang kesalahan tidak terlalu besar (maksimal 5\%), dan korelasi harus memiliki arah yang positif, yaitu $\mathrm{r}$ hitung $>$ r tabel (Silalahi 2012).

Selain itu dilakukan uji reliabilitas pada kuisioner penelitian untuk melihat tingkat kepercayaan kuesioner. Jika hasil pengukuran berulang menghasilkan hasil relatif sama, pengukuran tersebut dikatakan memiliki reliabilitas yang tinggi (Silalahi 2012). Uji validitas dan reliabilitas kuisioner dilakukan dengan perangkat lunak statistik.

\section{Penentuan Skor Persepsi}

Perhitungan skor persepsi akhir dilakukan dengan meratakan skor setiap aspek persepsi yaitu aspek nilai gizi dan kesehatan, aspek kualitas produk, aspek penanganan produk, aspek agama dan aspek harga. Nilai dari setiap variabel pernyataan adalah 1 hingga 4 . Pernyataan sangat tidak setuju diberi skor 1, pernyataan tidak setuju diberi skor 2, pernyataan setuju diberi skor 3 dan pernyataan sangat setuju diberi skor 4. Penentuan rentang skala untuk menentukan tingkatan persepsi dilakukan dengan menggunakan rumus berikut (Agustian 2011):

$$
\text { Rentang skala }=\frac{\text { nilai tertinggi-nilai terendah }}{\text { banyaknya skala }}=\frac{4-1}{4}=0.75
$$

Berdasarkan penghitungan tersebut didapatkan skala tingkatan persepsi seperti pada Tabel 1 .
Tabel 1. Skala tingkat persepsi responden

\begin{tabular}{cc}
\hline Nilai & Tingkat Persepsi \\
\hline $1.00-1.75$ & Sangat Buruk \\
$1.76-2.50$ & Buruk \\
$2.51-3.25$ & Baik \\
$3.26-4.00$ & Sangat Baik \\
\hline
\end{tabular}

\section{Uji Korelasi Rank Spearman}

Uji korelasi Rank Spearman digunakan untuk mengukur hubungan antar variabel yang memiliki skala ordinal. Variabel yang akan diukur hubungannya pada penelitian ini adalah persepsi dengan karakteristik konsumen. Berikut rumus uji korelasi Rank Spearman (Silalahi 2012):

$$
\mathrm{rs}=1-\frac{6 \sum \mathrm{d}^{2}}{\mathrm{n}\left(\mathrm{n}^{2}-1\right)}
$$

Keterangan:

$$
\begin{array}{ll}
\text { rs } & : \text { Nilai koefisien korelasi Sprearman; } \\
\text { d } & : \text { Selisih antara kedua perangkat peubah; dan } \\
\mathrm{n} & : \text { Banyaknya peubah. }
\end{array}
$$

\section{HASIL DAN PEMBAHASAN}

\section{Karakteristik Konsumen Bisnis Daging Sapi Beku di DKI Jakarta}

Konsumen bisnis membeli barang untuk dijual atau diproses menjadi barang lain dan dijual kembali (Sumarwan 2014). Kotler (2005) menyatakan, pasar bisnis terdiri dari semua organisasi yang memperoleh barang dan jasa untuk digunakan kembali guna memproduksi barang dan jasa lain yang dijual, disewakan, atau dipasok kepada pihak lain. Responden pada penelitian ini terdiri dari 90 usaha yang membeli daging sapi beku baik untuk dijual kembali maupun diolah menjadi beragam menu masakan. Terdapat beberapa karakteristik yang membedakan setiap usaha tersebut, diantaranya jenis usaha, skala usaha berdasarkan pendapatan per tahun, konsumsi daging sapi per bulan, serta rentang waktu usaha yang dapat dilihat pada Tabel 2.

\section{Jenis Usaha}

Konsumen bisnis yang mengonsumsi daging sapi beku dibagi menjadi dua golongan besar yaitu usaha yang menjual daging sapi beku dalam bentuk bahan pangan segar dan bentuk olahan daging sapi. Mayoritas responden merupakan usaha yang membeli daging sapi beku untuk diolah menjadi masakan. Menurut Kirbrandoko et al. (2015), produk yang terdiferensiasi akan menurunkan tingkat persaingan pasar, hal ini dapat menjadi alasan mengapa banyak responden yang memilih untuk menjual olahan daging sapi beku.

Jenis usaha yang paling banyak membeli daging sapi beku adalah usaha restoran yaitu 44.44\% (Tabel 2). Selanjutnya, olahan yang paling banyak dibuat oleh usaha restoran adalah soto dengan presentase $28.57 \%$, jenis soto 
Tabel 2. Karakteristik konsumen bisnis daging sapi beku

\begin{tabular}{|c|c|c|}
\hline Karakteristik & Frekuensi & $\begin{array}{c}\text { Persentase } \\
(\%) \\
\end{array}$ \\
\hline \multicolumn{3}{|l|}{ Jenis Usaha } \\
\hline Restoran & 40 & 44.44 \\
\hline Katering & 8 & 8.89 \\
\hline Hotel & 6 & 6.67 \\
\hline Supermarket & 11 & 12.22 \\
\hline Supplier & 7 & 7.78 \\
\hline Kios daging & 18 & 20 \\
\hline Total & 90 & 100 \\
\hline \multicolumn{3}{|l|}{ Pendapatan per tahun (Rp) } \\
\hline$\leq 300000000$ & 29 & 32.22 \\
\hline $300000001-2500000000$ & 34 & 37.78 \\
\hline $2500000001-50000000000$ & 27 & 30 \\
\hline Total & 90 & 100 \\
\hline \multicolumn{3}{|l|}{$\begin{array}{l}\text { Konsumsi daging sapi per bulan } \\
\text { (kg) }\end{array}$} \\
\hline$<10$ & 6 & 6.67 \\
\hline Nov-50 & 16 & 17.78 \\
\hline $51-200$ & 24 & 26.67 \\
\hline $201-500$ & 14 & 15.56 \\
\hline $501-1000$ & 7 & 7.78 \\
\hline$>1000$ & 23 & 25.56 \\
\hline Total & 90 & 100 \\
\hline \multicolumn{3}{|l|}{ Lama waktu usaha (tahun) } \\
\hline$<5$ & 35 & 38.89 \\
\hline $5-O c t$ & 23 & 25.56 \\
\hline Oct-20 & 25 & 27.78 \\
\hline$>20$ & 7 & 7.78 \\
\hline Total & 90 & 100 \\
\hline \multicolumn{3}{|c|}{$\begin{array}{l}\text { Jenis daging sapi yang disediakan } \\
\text { responden }\end{array}$} \\
\hline Daging Sapi Segar & 16 & 25 \\
\hline Daging Sapi Beku & 35 & 54.69 \\
\hline Daging Sapi Dingin & 13 & 20.31 \\
\hline Total & 64 & 100 \\
\hline \multicolumn{3}{|l|}{$\begin{array}{l}\text { Jenis olahan daging sapi yang } \\
\text { dijual responden }\end{array}$} \\
\hline Empal & 7 & 6.67 \\
\hline Rendang & 10 & 9.52 \\
\hline Soto & 30 & 28.57 \\
\hline Sop & 14 & 13.33 \\
\hline Steak & 12 & 11.43 \\
\hline Bakso & 3 & 2.86 \\
\hline Rawon & 7 & 6.67 \\
\hline Tunis Daging & 7 & 6.67 \\
\hline Lainnya & 15 & 14.29 \\
\hline Total & $105^{*}$ & 100 \\
\hline
\end{tabular}

Tabel 2. Karakteristik konsumen bisnis daging sapi beku (lanjutan)

\begin{tabular}{|c|c|c|}
\hline Karakteristik & Frekuensi & $\begin{array}{l}\text { Persentase } \\
\quad(\%)\end{array}$ \\
\hline \multicolumn{3}{|c|}{$\begin{array}{l}\text { Bagian-bagian daging sapi beku } \\
\text { yang dikonsumsi responden }\end{array}$} \\
\hline Silverside & 26 & 7.58 \\
\hline Topside & 28 & 8.16 \\
\hline Kepala & 21 & 6.12 \\
\hline Rib & 39 & 11.37 \\
\hline Chuck & 29 & 8.45 \\
\hline Blade & 22 & 6.41 \\
\hline Brisket & 18 & 5.25 \\
\hline Flank & 17 & 4.96 \\
\hline Cuberoll & 17 & 4.96 \\
\hline Loin & 27 & 7.88 \\
\hline Knuckle & 22 & 6.41 \\
\hline Shank & 23 & 6.71 \\
\hline Eyeround & 27 & 7.87 \\
\hline FQ (campuran) & 27 & 7.87 \\
\hline Total & $343 *$ & 100 \\
\hline \multicolumn{3}{|c|}{ Bentuk pembelian daging sapi } \\
\hline Potongan daging beku & 78 & 63.93 \\
\hline Potongan daging segar & 40 & 32.79 \\
\hline Karkas segar & 4 & 2.29 \\
\hline Total & $122 *$ & 100 \\
\hline
\end{tabular}

*jawaban responden dapat lebih dari 1

yang dibuat yaitu soto betawi yang menggunakan daging sapi sebagai bahan utamanya. Banyaknya responden yang memilih soto menjadi produknya dapat disebabkan oleh faktor sosial dan budaya yaitu soto betawi yang merupakan makanan khas jakarta sehingga tingginya antusiasme dari konsumen untuk mengonsumsi soto betawi.

Daging iga merupakan bagian yang paling banyak dibeli oleh konsumen bisnis dengan persentase sebesar $11.37 \%$. Konsumen bisnis lebih banyak membeli daging sapi dalam bentuk beku yaitu sebesar $63.93 \%$. Selanjutnya, konsumen bisnis lebih banyak menjualnya kembali dalam bentuk daging sapi beku persentase $54.69 \%$. Selain daging sapi beku, responden ini menyediakan bentuk yang lain yaitu daging sapi segar dan daging sapi dingin (chilled). Daging sapi segar biasanya banyak disediakan oleh pedagang daging di pasar tradisional. Hal ini terjadi karena masih adanya permintaan konsumen terhadap daging sapi segar. Daging sapi dingin biasanya disediakan oleh swalayan karena dilengkapi dengan adanya display berpendingin.

\section{Skala Usaha Berdasarkan Pendapatan Per Tahun}

Pendapatan merupakan imbalan yang diterima oleh suatu usaha dari hasil menjual produknya. Pendapatan menjadi sumber material yang penting bagi konsumen bisnis untuk dapat melakukan kegiatan usahanya (Sumarwan 2014). Pendapatan sangat dipengaruhi oleh permintaan konsumen. Semakin banyak permintaan 
konsumen, maka penjualan akan semakin meningkat dan diikuti dengan meningkatnya pendapatan (Kibrandoko et al. 2015). Berdasarkan undang-undang nomor 20 tahun 2008 tentang UMKM, pendapatan per tahun dapat menjadi indikator skala usaha. Skala usaha yang di analisis pada penelitian ini terdiri dari skala usaha mikro, skala usah kecil, dan skala usaha menengah.

Mayoritas responden merupakan usaha berskala mikro yang merupakan restoran (rumah makan) dengan pendapatan per tahun kurang dari sama dengan Rp 300000 000 yaitu sebanyak $32.22 \%$. Sebanyak $37.78 \%$ responden merupakan usaha berskala kecil dengan pendapatan per tahun lebih dari Rp 300000000 hingga Rp 2500000 000. Usaha skala kecil ini didominasi oleh pasar swalayan. Lebih lanjut, 30\% responden merupakan usaha berskala menengah seperti katering, supplier, kios daging, dan hotel dengan pendapatan per tahun Rp 2500000000 hingga Rp 50000000000 .

\section{Konsumsi Daging Sapi Per Bulan}

Daging sapi yang dikonsumsi oleh konsumen dapat berupa daging sapi segar, daging sapi dingin dan daging sapi beku. Konsumsi merupakan kegitan memakai atau menghabiskan barang (Sumarwan 2014). Jumlah konsumsi daging sapi per bulan yang paling banyak yaitu 51-200 kg dan $>1000 \mathrm{~kg}$ sebesar $26.67 \%$ dan $25.56 \%$.

Produk yang banyak dikonsumsi menandakan bahwa produk tersebut diminati oleh konsumen. Sumarwan (2014) menyatakan, jumlah konsumsi menggambarkan kuantitas produk yang digunakan oleh konsumen, sehingga dapat menjadi indikator besarnya permintaan konsumen terhadap suatu produk. Jenis usaha yang mengonsumsi daging sapi dalam jumlah besar adalah usaha yang menjual daging sapi dalam bentuk bahan segar, yaitu supplier, kios daging dan supermarket serta untuk olahan adalah usaha katering.

\section{Lama Waktu Usaha}

Mayoritas responden memiliki rentang waktu usaha kurang dari 5 tahun yaitu sebesar 38.89\% yang didominasi oleh usaha rumah makan. Besarnya prospek usaha di dunia kuliner menyebabkan banyak pelaku usaha yang ingin mencoba masuk dalam pasar tersebut sehingga banyak usaha yang belum lama berdiri. Semakin lama rentang waktu usaha maka usaha tersebut semakin banyak memiliki pengalaman dan pengetahuan mengenai perilaku pasar dan perilaku konsumen.

Responden semakin mengetahui karakteristik daging sapi dan sudah dapat menentukan jenis daging sapi yang akan dibeli, asal dan jumlahnya, selain itu semakin banyak juga relasi dan konsumen yang dapat dijaring oleh usaha tersebut (Vijayanti 2016). Sedikit usaha yang dapat bertahan untuk waktu yang lama. Hal ini dibuktikan dengan persentase paling sedikit untuk rentang usaha lebih dari 20 tahun yaitu sebanyak $7.78 \%$.

\section{Perilaku Pembelian Daging Sapi Beku oleh Konsumen Bisnis di DKI Jakarta}

Perilaku konsumen merupakan perilaku yang memperlihatkan konsumen dalam mencari, membeli, menggunakan, mengevaluasi, dan menghabiskan produk serta jasa yang mereka harapkan dapat memuaskan kebutuhan mereka. Sebelum memutuskan untuk mengonsumsi suatu barang atau jasa, tentunya konsumen akan melalui serangkaian tahapan yang menentukan keputusan akhir pembelian suatu barang atau jasa (Sumarwan 2014). Proses pengambilan keputusan oleh konsumen bisnis menurut Kotler (2005) dibagi menjadi 5 tahapan, yaitu: pengenalan kebutuhan, pencarian informasi, evaluasi alternatif, keputusan pembelian, dan perilaku setelah pembelian.

\section{Pengenalan Kebutuhan}

Kebutuhan daging sapi sebagai bahan baku untuk menjalankan usaha merupakan masalah yang dialami responden. Proses pengenalan kebutuhan, muncul saat konsumen menghadapi suatu masalah (Sumarwan 2014), sehingga diperlukan pengenalan kebutuhan terhadap daging sapi. Responden memiliki berbagai alasan lebih memilih daging sapi beku untuk memenuhi kebutuhannya. Alasan terbanyak responden dalam mengonsumsi daging sapi beku adalah karena penyimpanan dengan persentase $24.64 \%$. Sebaran alasan responden dalam mengonsumsi daging sapi beku dapat dilihat pada Tabel 3 .

Tabel 3. Alasan mengonsumsi daging sapi beku

\begin{tabular}{lcc}
\hline \multicolumn{1}{c}{$\begin{array}{c}\text { Alasan mengonsumsi daging sapi } \\
\text { beku }\end{array}$} & Frekuensi & $\begin{array}{c}\text { Persentase } \\
(\%)\end{array}$ \\
\hline Ketersediaan di pasaran & 30 & 21.74 \\
Harga yang lebih terjangkau & 26 & 18.84 \\
Penyimpanan & 34 & 24.64 \\
Kualitas terjamin & 18 & 13.04 \\
Permintaan konsumen & 30 & 21.74 \\
Total & $138 *$ & 100 \\
\hline
\end{tabular}

*jawaban responden dapat lebih dari 1

Responden membeli daging sapi beku karena masa simpannya yang lebih lama dan biasanya responden menyimpan daging sapi segar yang tidak habis dengan dibekukan untuk mencegah kebusukan dan dapat dijual kembali dengan harga yang lebih murah. Sebanyak $21.74 \%$ responden memilih ketersediaan daging di pasar sebagai alasan mengonsumsi daging sapi beku.

Persentase setiap bagian daging berbeda-beda satu sama lain sedangkan terdapat beberapa jenis olahan yang membutuhkan daging dengan kriteria khusus seperti daging kepala, buntut, dan daging khas yang memiliki persentase kecil pada karkas. Hal ini yang mendasari responden memilih daging sapi beku.

\section{Pencarian Informasi}

Konsumen perlu mencari informasi mengenai produk yang akan digunakan. Pencarian informasi ini dapat dilakukan melalui berbagai cara. Informasi mengenai suatu produk dapat didapatkan melalui dua sumber yaitu pencarian internal yang tersimpan dalam ingatan konsumen dan pencarian eksternal atau informasi dari luar. Terdapat banyak faktor yang mempengaruhi proses pencarian informasi diantaranya yaitu karakteristik konsumen yang terdiri dari pengetahuan dan pengalaman konsumen, kepribadian konsumen, dan keadaan demografis (Sumarwan 2014). Sebaran sumber informasi daging sapi beku dapat dilihat pada Tabel 4. 
Tabel 4. Sumber informasi daging sapi beku

\begin{tabular}{lcc}
\hline \multicolumn{1}{c}{ Sumber Informasi } & Frekuensi & Persentase (\%) \\
\hline Pengalaman pribadi konsumen & 81 & 66.94 \\
Promosi produsen & 26 & 21.49 \\
Rekomendasi orang lain & 14 & 11.57 \\
Total & $121^{*}$ & 100 \\
\hline
\end{tabular}

*jawaban responden dapat lebih dari 1

Sumber informasi utama mengenai daging sapi beku di wilayah DKI Jakarta adalah pengalaman pribadi dari konsumen yaitu sebesar $66.94 \%$. Mayoritas responden mendapatkan kontak produsen daging sapi beku melalui pencarian sendiri di pasar tradisional maupun supplier, dan telah memiliki hubungan dengan supplier atau pedagang daging sapi beku. Konsumen yang telah memiliki banyak pengalaman mungkin tidak termotivasi untuk mencari informasi lebih banyak.

\section{Evaluasi Alternatif}

Setelah mendapatkan informasi mengenai daging sapi beku, konsumen perlu melakukan evaluasi mengenai daging sapi beku yang akan dibeli. Diperlukan suatu kriteria evaluasi dalam proses evaluasi alternatif. Sumarwan (2014) menyatakan, kriteria evaluasi adalah atribut atau karakteristik dari produk yang akan dibeli. Responden dapat memilih lebih dari satu atribut untuk menjadi pertimbangan dalam menentukan daging sapi beku yang akan dibeli sesuai dengan kebutuhannya. Atribut yang paling banyak dijadikan pertimbangan oleh konsumen adalah kualitas dengan persentase sebesar $46.58 \%$, Sebaran atribut pertimbangan responden dapat dilihat pada Tabel 5 .

Tabel 5. Atribut pertimbangan dalam mengonsumsi daging sapi beku

\begin{tabular}{lcc}
\hline \multicolumn{1}{c}{ Atribut } & Frekuensi & Persentase (\%) \\
\hline Kualitas & 68 & 46,58 \\
Harga & 33 & 22,6 \\
Bagian daging sapi & 27 & 18,49 \\
Lainnya & 18 & 12,33 \\
Total & $146^{*}$ & 100 \\
\hline
\end{tabular}

*jawaban responden dapat lebih dari 1

Keputusan akhir pembelian pada konsumen bisnis ditentukan oleh pihak tertentu. Keputusan akhir pembelian daging sapi dilakukan oleh pemilik usaha atau manajer. Sebanyak $75.56 \%$ pihak yang memutuskan pembelian produk adalah pemilik perusahaan dan $24.44 \%$ adalah manajer. Responden dengan pemegang keputusan pembelian pemilik usaha biasanya adalah usaha dengan skala mikro hingga kecil, sedangkan usaha dengan manajer sebagai pihak pemegang keputusan akhir biasanya usaha dengan skala menengah dan besar seperti supermarket, hotel, dan restoran franchise. Selain itu terdapat pihak lain yang mempengaruhi keputusan pembelian diantaranya staff bagian dapur.

\section{Proses Pembelian}

Setelah melewati proses pengambilan keputusan, konsumen selanjutnya berhak memutuskan untuk membeli atau tidak daging beku tersebut. Adanya keinginan untuk membeli daging sapi, akan mendorong konsumen untuk mencari produsen. Sumarwan (2014) menyatakan, proses pembelian dibagi menjadi 4 tahapan yaitu berhubungan dengan produsen, mencari produk, transaksi dan konsumsi. Kontak dengan produsen akan menentukan tempat konsumen membeli daging sapi tersebut. Sebaran produsen daging sapi beku yang dibeli oleh responden dapat dilihat pada Tabel 6 .

Tabel 6. Produsen daging sapi beku

\begin{tabular}{lcc}
\hline \multicolumn{1}{r}{ Produsen } & Frekuensi & Persentase (\%) \\
\hline Pasar tradisional & 32 & 34.04 \\
Supermarket & 4 & 4.25 \\
Supplier & 50 & 53.19 \\
Impor & 4 & 4.25 \\
RPH & 4 & 4.25 \\
Total & $94^{*}$ & 100 \\
\hline
\end{tabular}

*jawaban responden dapat lebih dari 1

Mayoritas responden membeli daging sapi beku di supplier dengan presentase sebesar $53.19 \%$. Responden memilih untuk membeli daging sapi beku di supplier dan pasar tradisional karena harganya yang lebih murah. Responden yang mendapatkan pasokan daging sapi beku dari supplier adalah kios daging di pasar tradisional, beberapa rumah makan, hotel, dan katering.

Daging sapi tergolong kepada bahan habis pakai. Konsumen akan membeli lagi barang tersebut jika sudah habis digunakan. Konsumen menghabiskan barang yang dibelinya dalam jangka waktu yang berbeda-beda, ada yang dalam waktu cepat dan waktu yang lama. Frekuensi pembelian daging sapi dapat dilihat pada Tabel 7.

Tabel 7. Frekuensi pembelian daging sapi

\begin{tabular}{lll}
\hline Frekuensi Pembelian & Frekuensi & Persentase (\%) \\
\hline Setiap hari & 52 & 57,78 \\
2-4 hari sekali & 14 & 15,56 \\
5-7 hari sekali & 14 & 15,56 \\
2 minggu sekali & 7 & 7,78 \\
Sebulan sekali & 1 & 1,11 \\
Tidak tentu & 2 & 2,22 \\
Total & 90 & 100 \\
\hline
\end{tabular}

Frekuensi pembelian yang paling sering dilakukan oleh konsumen adalah setiap hari dengan responden sejumlah $57.78 \%$. Responden yang melakukan pembelian daging sapi setiap hari adalah kios daging dan rumah makan. Responden tersebut melakukan pembelian tiap hari karena keharusan berjualan hampir setiap hari dan telah memperkirakan berapa daging yang dibutuhkan dalam 1 hari sehingga jarang ada yang bersisa. Selain itu responden juga menginginkan daging yang baru setiap harinya. Banyak penjual daging di pasar tradisional yang tidak 
memiliki freezer sebagai tempat penyimpanan, sehingga daging tidak bisa disimpan.

Pembelian daging sapi dilakukan dengan 2 cara yaitu pemesanan dan langsung. Responden yang mendapatkan daging sapi dari supplier biasanya akan melakukan pembelian melalui pemesanan sedangkan responden yang membeli daging sapi dari pasar dan supermarket akan membeli secara langsung. Sebanyak $44.44 \%$ responden melakukan pembelian secara langsung dan $55.56 \%$ responden melakukan pemesanan untuk membeli daging sapi yang dibutuhkan.

Cara pembayaran yang dilakukan oleh responden juga dibagi 2 yaitu secara tunai dan berhutang. Sebanyak $60 \%$ responden melakukan pembayaran secara tunai sedangkan $40 \%$ responden melakukan pembayaran dengan berhutang. Responden yang melakukan pembayaran secara tunai biasanya adalah responden yang membeli daging secara langsung, sedangkan responden dengan cara pembelian berhutang biasanya melakukan pembelian dengan cara memesan. Responden akan membayar dengan cara tempo. Uang dibayarkan setelah daging habis atau dibayarkan dalam jangka waktu yang sudah ditentukan.

\section{Perilaku Setelah Pembelian}

Setelah melakukan pembelian terhadap daging sapi, maka akan timbul pengalaman dan pengetahuan konsumen mengenai produk tersebut, proses ini disebut sebagai proses evaluasi alternatif. Hasil dari proses ini adalah perasaan puas atau tidak puas terhadap suatu produk (Sumarwan 2014). Kepuasan akan mendorong konsumen untuk membeli lagi tetapi sebaliknya rasa tidak puas akan menyebabkan konsumen kecewa dan berhenti melakukan pembelian atau mencari produsen lain.

Sebanyak 90\% responden memutuskan akan terus mengonsumsi daging sapi beku karena merasakan adanya beberapa keuntungan yang diperoleh diantaranya keuntungan meningkat karena harga yang lebih murah, kualitas terjamin, masa simpan lebih lama dan selalu tersedia di pasar (Tabel 8).

Tabel 8. Keputusan responden untuk mengonsumsi kembali daging sapi beku

\begin{tabular}{lcc}
\hline \multicolumn{1}{c}{ Frekuensi Pembelian } & Frekuensi & Persentase (\%) \\
\hline Mengonsumsi kembali & 81 & 90 \\
Tidak mengonsumsi kembali & 9 & 10 \\
Total & 90 & 100 \\
\hline
\end{tabular}

Sebanyak $10 \%$ responden memutuskan untuk berhenti membeli daging sapi beku karena beberapa alasan diantaranya pernah mendapatkan daging sapi dengan kualitas yang buruk seperti penyusutan yang tinggi, rasa yang kurang enak, dan sulitnya pengolahan daging sapi beku.

\section{Persepsi Konsumen bisnis terhadap Daging Sapi Beku}

Persepsi dapat didefinisikan sebagai proses bagaimana stimuli-stimuli tersebut diseleksi, diorganisasikan dan diinterpretasikan. Pengenalan atas suatu objek jelas, gerakan, intensitas, dan aroma akan mempengaruhi persepsi (Setiadi 2008). Persepsi memiliki peran yang penting dalam menentukan tindakan konsumen, kebiasaan, sikap dan keputusan membeli (Solomon 2002). Rataan skor persepsi responden terhadap daging sapi beku dapat dilihat pada Tabel 9.

Persepsi konsumen terhadap daging sapi beku ditinjau dari beberapa aspek yaitu kandungan gizi dan kesehatan, kualitas produk, penanganan produk, agama, dan harga. Responden memiliki persepsi yang baik terhadap aspek kandungan gizi dan kesehatan yang menyatakan bahwa daging sapi beku memiliki kandungan gizi yang baik dan aman dikonsumsi, dengan rataan skor 3.08 .

Persepsi konsumen ditinjau dari aspek kualitas produk diukur menggunakan variabel yang menyatakan bahwa daging sapi beku memiliki kualitas fisik dan organoleptik yang baik, serta diproses dengan higienis. Menurut Zhou et al. (2010) dalam Cassius (2017), pembekuan akan menurunkan daya mengikat air yang akan meningkatkan drip loss. Menurut Feiner (2006), persentase drip loss daging sapi beku yang dithawing dengan air mengalir berkisar 8\%-12\%. Besarnya drip loss akan mempengaruhi bobot akhir daging sapi. Persentase drip loss dapat dikurangi dengan menerapkan metode pembekuan rapid freezing, karena kristal es yang dihasilkan lebih kecil, sehingga tidak merusak struktur daging. Proses pembekuan tidak berpengaruh nyata pada keempukan daging. Keempukan daging lebih dipengaruhi oleh proses aging dan kondisi ternak sebelum disembelih. Perubahan yang terjadi pada daging beku tidak terlalu signifikan sehingga masih bisa diterima oleh konsumen.

Warna merupakan salah satu atribut paling penting yang menjadi indikator tingkat kesegaran dan kualitas daging. Konsumen cenderung lebih memilih daging dengan warna merah segar (James dan James 2010). Proses pembekuan dapat mempertahankan warna daging, sehingga setelah dithawing warna daging beku sama seperti daging segar (Cassius 2017). Perubahan rasa sangat sulit diketahui karena masih belum ada parameter khusus untuk mengukur rasa daging, namun menurut Muela (2010) terjadi oksidasi lemak selama penyimpanan daging beku yang akan meyebabkan terbentuknya produk sekunder dari oksidasi lemak, namun panelis tidak merasakan perubahan rasa dari akibat proses oksidasi tersebut. Rataan skor persepsi konsumen dari aspek kualitas produk yaitu 2.87 yang termasuk dalam rentang nilai persepsi yang baik.

Kualitas yang mendapatkan perhatian paling banyak adalah susut masak dan rasa daging sapi beku. Susut masak berkaitan dengan drip loss. Semakin tinggi drip loss maka bobot daging sapi semakin berkurang (Feiner 2006). Responden yang memiliki persepsi buruk berpendapat bahwa daging sapi beku lebih alot, susut masaknya tinggi dan rasanya tidak seenak daging segar. Persepsi buruk ini dapat disebabkan adanya pengalaman buruk yang terus diingat oleh responden (Sumarwan 2014).

Proses pembekuan merupakan salah satu teknologi pengawetan yang dapat memperpanjang umur simpan daging sapi (Kadim dan Mahgoub 2007). Menurut daging sapi beku dapat disimpan selama 1 tahun. Persepsi konsumen terhadap daging sapi beku juga ditinjau dari aspek penangan produk. Persepsi ini diukur dengan pernyataan bahwa daging sapi beku mudah untuk ditangani dan memiliki masa simpan yang lama. Berdasarkan aspek 
Tabel 9. Rataan skor persepsi responden terhadap daging sapi beku

\begin{tabular}{|c|c|c|c|c|}
\hline No & Aspek & Sub Aspek & Variabel & $\begin{array}{c}\text { Rataan } \\
\text { Skor }\end{array}$ \\
\hline \multirow[t]{5}{*}{1} & \multirow{4}{*}{$\begin{array}{l}\text { Kandungan gizi } \\
\text { dan kesehatan }\end{array}$} & \multirow[t]{2}{*}{ Kandungan gizi } & Daging sapi beku memiliki kandungan gizi yang baik & 2.89 \\
\hline & & & Proses pembekuan tidak mengurangi kandungan gizi pada daging sapi & 2.49 \\
\hline & & \multirow[t]{2}{*}{ Kesehatan } & Daging sapi beku baik untuk dikonsumsi & 3.56 \\
\hline & & & Mengonsumsidaging sapi beku tidak berbahaya untuk kesehatan & 3.37 \\
\hline & Rataan skor aspek & & & 3.08 \\
\hline \multirow[t]{13}{*}{2} & \multirow[t]{12}{*}{ Kualitas produk } & \multirow[t]{7}{*}{ Kualitas fisik } & Daging sapi beku memiliki kualitas yang baik & 2.96 \\
\hline & & & Pembekuan tidak merubah kualitas daging sapi & 2.76 \\
\hline & & & Daging sapi beku memiliki tingkat kekenyalan yang baik & 2.94 \\
\hline & & & Daging sapi beku memiliki tekstur serat yang baik & 2.98 \\
\hline & & & Daging sapi beku empuk saat diolah & 2.98 \\
\hline & & & Daging sapi beku sedikit mengalami penyusutan setelah diolah & 2.51 \\
\hline & & & Daging sapi beku memiliki lebih sedikit lemak & 2.59 \\
\hline & & \multirow[t]{3}{*}{ Organoleptik } & Daging sapi beku memiliki rasa yang enak & 2.84 \\
\hline & & & Daging sapi beku memiliki aroma khas daging & 2.96 \\
\hline & & & Penampilan daging sapi beku terlihat baik dan menarik & 2.78 \\
\hline & & \multirow[t]{2}{*}{ Kebersihan } & Daging sapi beku diproses dengan bersih dan higienis & 3.10 \\
\hline & & & Daging yang disimpan pada suhu pembekuan lebih higienis & 3.06 \\
\hline & Rataan skor aspek & & & 2.87 \\
\hline \multirow[t]{3}{*}{3} & \multirow{2}{*}{$\begin{array}{l}\text { Penanganan } \\
\text { produk }\end{array}$} & & Daging sapi beku tidak mudah busuk & 3.31 \\
\hline & & & Daging sapi beku lebih mudah disimpan dan ditangani & 2.92 \\
\hline & Rataan skor aspek & & & 3.12 \\
\hline \multirow[t]{3}{*}{4} & Agama & \multirow[t]{2}{*}{-} & Daging sapi beku jelas kehalalannya & 3.22 \\
\hline & & & Daging sapi beku berasal dari sapi yang sehat dan baik. & 3.22 \\
\hline & Rataan skor aspek & & & 3.22 \\
\hline \multirow[t]{3}{*}{5} & Harga & \multirow[t]{3}{*}{-} & Harga daging sapi beku lebih terjangkau & 3.27 \\
\hline & Rataan skor aspek & & & 3.27 \\
\hline & Rataan skor akhir & & & 3.12 \\
\hline
\end{tabular}

tersebut, responden memiliki rataan skor persepsi 3.12 yang tergolong pada rentang skor persepsi yang baik. Mayoritas responden tidak merasa kesulitan dengan adanya proses thawing tersebut. Selain itu responden berpendapat bahwa daging sapi beku sudah bersih dari lemak sehingga responden tidak perlu melakukan trimming lagi.

Mayoritas pendududuk Indonesia beragama Islam, sehingga isu mengenai pangan yang halal dan thayyib merupakan hal yang penting. Berdasarkan Permentan Nomor 17 tahun 2016, daging sapi beku yang berasal dari luar negeri harus memenuhi persyaratan label dan kemasan yaitu mencantumkan dalam bahasa Indonesia dan bahasa inggris: Negara tujuan Indonesia; nomor kontrol veteriner (NKV); tanggal penyembelihan; pemotongan dan tanggal produksi; jenis ternak, jumlah dan jenis potongan daging; serta label halal. Inilah yang menjadi dasar kepercayaan konsumen pada kehalalan daging sapi beku. Responden memiliki persepsi agama dengan rataan skor 3.22 yang tergolong pada tingkatan persepsi yang baik.

Harga merupakan salah satu atribut penting dari suatu produk. Pengukuran persepsi terhadap harga menggunakan pernyataan bahwa daging sapi beku memiliki harga yang lebih terjangkau. Bappenas (2015) menyatakan, rantai distribusi yang lebih singkat menyebabkan harga daging sapi beku menjadi lebih murah dibandingkan dengan daging sapi segar. Rataan skor persepsi ditinjau dari aspek harga yaitu 3.27 yang menunjukkan bahwa responden memiliki persepsi yang sangat baik terhadap harga daging sapi beku. Berdasarkan rataan aspek keempat aspek di atas didapatkan skor rataan akhir persepsi sebesar 3.12 yang menunjukkan bahwa persepsi konsumen bisnis terhadap daging sapi beku di wilayah DKI Jakarta adalah baik.

\section{Hubungan Persepsi dan Karakteristik Konsumen Daging Sapi Beku}

Terdapat 4 karakteristik konsumen yang diukur hubungannya dengan persepsi terhadap daging beku. Sumarwan (2014) menyatakan, persepsi konsumen terhadap suatu produk dapat dipengaruhi oleh faktor internal, salah satunya karakteristik konsumen. Karakteristik tersebut yaitu jenis usaha berdasarkan bentuk penjualan daging sapi beku, skala usaha berdasarkan pendapatan per tahun, konsumsi 
daging per bulan, dan lama waktu usaha. Hasil analisis Rank Spearman dapat dilihat pada Tabel 10.

Tabel 10. Hubungan antara karakteristik konsumen bisnis dengan persepsi terhadap daging sapi beku

\begin{tabular}{|c|c|c|c|c|}
\hline No & $\begin{array}{c}\text { Karakteristik } \\
\text { konsumen }\end{array}$ & $\begin{array}{c}\text { Koefisien } \\
\text { korelasi }\end{array}$ & $\begin{array}{l}\text { Signifikasi } \\
\text { (P) }\end{array}$ & Keterangan \\
\hline 1 & Jenis usaha & -0.206 & 0.051 & $\begin{array}{l}\text { Hubungan } \\
\text { tidak searah, } \\
\text { sangat lemah } \\
\text { dan tidak } \\
\text { signifikan }\end{array}$ \\
\hline 2 & Skala usaha & 0.251 & 0.017 & $\begin{array}{l}\text { Hubungan } \\
\text { searah, sangat } \\
\text { lemah dan } \\
\text { signifikan }\end{array}$ \\
\hline 3 & $\begin{array}{l}\text { Konsumsi } \\
\text { daging sapi } \\
\text { per bulan }\end{array}$ & 0.323 & 0.002 & $\begin{array}{l}\text { Hubungan } \\
\text { searah, lemah } \\
\text { dan signifikan }\end{array}$ \\
\hline 4 & $\begin{array}{l}\text { Lama waktu } \\
\text { usaha }\end{array}$ & -0.100 & 0.349 & $\begin{array}{l}\text { Hubungan } \\
\text { tidak searah, } \\
\text { sangat lemah } \\
\text { dan tidak } \\
\text { signifikan }\end{array}$ \\
\hline
\end{tabular}

Hasil uji korelasi Rank Spearman menunjukkan bahwa variabel jenis usaha dan rentang waktu usaha tidak memiliki hubungan yang berarti dengan tingkat persepsi konsumen terhadap daging sapi beku.

Skala usaha memiliki hubungan yang signifikan dan searah dengan persepsi konsumen $(\mathrm{P}<0.05)$. hal ini menunjukkan bahwa semakin besar skala usaha maka semakin baik persepsi konsumen bisnis terhadap daging sapi beku. Skala usaha berkaitan dengan pendapatan. Semakin besar skala usaha maka semakin besar pula pendapatanya. Selain itu semakin besar skala usaha maka konsumsi daging sapi beku akan meningkat.

Sejalan dengan hubungan signifikan skala usaha dengan persepsi konsumen, jumlah konsumsi daging sapi per bulan memiliki hubungan yang signifikan $(\mathrm{P}<0.05)$ dan searah dengan tingkat persepsi konsumen bisnis terhadap daging sapi beku. Hal ini menunjukkan adanya hubungan yang berarti antara tingkat persepsi konsumen dengan jumlah konsumsi daging sapi per bulan. Hubungan yang searah menunjukkan bahwa semakin banyak konsumsi daging sapi maka akan semakin baik persepsi konsumen terhadap daging sapi beku. Konsumsi yang semakin meningkat menunjukkan bahwa responden memiliki persepsi yang baik. Konsumen yang sering membeli daging sapi beku akan semakin banyak memiliki pengetahuan dan pengalaman terkait daging sapi beku. Menurut Sumarwan (2014), pengetahuan dan pengalaman masa lalu konsumen berpengaruh pada persepsi. Pengetahuan yang baik akan menimbulkan persepsi yang baik juga.

\section{KESIMPULAN}

Konsumen bisnis daging sapi beku di wilayah DKI Jakarta merupakan jenis usaha yang membeli daging sapi beku untuk diolah kembali dengan jumlah konsumsi daging sebanyak 51-200 kg dan lebih dari $1000 \mathrm{~kg}$ per bulan, berskala usaha mikro dengan pendapatan per tahun maksimal Rp 300000000 dan lama waktu usaha kurang dari 5 tahun. Konsumen bisnis di wilayah DKI Jakarta memiliki persepsi yang baik terhadap daging sapi beku. Aspek kualitas produk merupakan aspek dengan skor terendah dan aspek dengan skor tertinggi yaitu aspek harga. Konsumsi daging sapi per bulan dan skala usaha mempengaruhi persepsi konsumen terhadap daging sapi beku.

\section{UCAPAN TERIMA KASIH}

Ucapan terimakasih disampaikan pada NICHENUFFIC yang telah mendanai penelitian ini serta kepada semua tim peneliti dan responden yang terlibat dalam penelitian ini.

\section{DAFTAR PUSTAKA}

Bappenas (Badan Perencanaan Pembangunan Nasional). 2015. Studi identifikasi ketahanan pangan dan preferensi konsumen tehadap konsumsi bahan pangan pokok daging. [Internet]. [diunduh 2018 Sep 02]. Tersedia pada https://www.bappenas.go.id.

BPS (Badan Pusat Statistik Indonesia). 2009. Kota Jakarta dalam angka. Jakarta (ID): BPS Kota Jakarta.

BPS (Badan Pusat Statistik Indonesia). 2013. Survei Ekonomi Nasional 2013: Jakarta (ID): Badan Pusat Statistik Jakarta.

BSN (Badan Standarisasi Nasional). 2008. SNI 3932:2008 Tentang Mutu Karkas dan Daging Sapi. Jakarta (ID): Badan Standarisasi Nasional.

Kementan (Kementrian Pertanian). 2016. Peraturan Menteri Pertanian Republik Indonesia Nomor 17/ Permentan/PK.450/5/2016 Tentang Pemasukan Daging Tanpa Tulang dalam Hal Tertentu yang Berasal dari Negara atau Zona dalam Suatu Negara Asal Pemasukan. [Internet]. [diunduh 2018 Sep 02]. Tersedia pada: https://perundangan.pertanian.go.id.

Pemerintah Republik Indonesia. 2008. Undang-undang Republik Indonesia Nomor 20 Tahun 2008 Tentang Usaha Mikro, Kecil dan Menengah (UMKM). [Internet]. [diunduh 2018 Jul 19]. Tersedia pada: https://www.bi.go.id/id/tentang-bi/uubi/documents/ UU20Tahun2008UMKM.

Agustian, H. 2011. Analisis persepsi konsumen terhadap daging kelinci di kota Bogor [skripsi]. Bogor (ID): Institut Pertanian Bogor.

Cassius, E. O., W. B. Benjamin, A. F. Michael, \& L. H. David. 2017. Long-term red meat preservation using chilled and frozen storage combination: A review. Meat Science. 125: 84-94.

Dewi, S. 2012. Populasi mikroba dan sifat fisik daging sapi beku selama penyimpanan. J Agri Sains. 3(4):1-12.

Dwi, A. 2016. Persepsi Konsumen terhadap Aspek Gizi dan Kesehatan Pangan Organik. [skripsi]. Bogor (ID): 
Institut Pertanian Bogor.

Fajrin, F. 2016. Tingkat pemahaman konsumen ibu rumah tangga terhadap daging sapi yang halal dan thayyib di kota Bogor [skripsi]. Bogor (ID): Institut Pertanian Bogor.

Feiner, G. 2006. Meat Products Handbook Practical Science and Technology. New York (USA): CRC Pr.

Gantina, A. 2006. Persepsi Konsumen terhadap Aspek Gizi dan Kesehatan Pangan Organik. [skripsi]. Bogor (ID): Institut Pertanian Bogor.

James, C., \& S. James. 2010. Freezing/Thawing: Handbook of Meat Processing. Iowa (USA): Blackwell Pub.

Kadim, I., \& O. Mahgoub. 2007. Postharvest Handling of Red Meat: Handbook of Food Preservation. Ed ke-2. New York (US): CRC Pr.

Kibrandoko, et al. 2015. Pemasaran Strategik: Perspektif Perilaku Konsumen dan Marketing Plan. Bogor (ID): IPB Pr.

Kotler, P. 2005. Manajemen Pemasaran. Jilid I. Jakarta (ID): Indeks.

Rakhmat, J. 2010. Psikologi Komunikasi. Bandung (ID): Rosdakarya Group.

Sarassati, T., \& K. Karang. 2015. Kualitas Daging Sapi Wagyu dan Daging Sapi Bali yang Disimpan pada Suhu $-19^{\circ} \mathrm{C}$. Indonesia Medicus Veterinus. 4(4): 178-185.
Setiadi, N. 2008. Perilaku Konsumen: Konsep dan Implikasi untuk Strategi dan Penelitian Pemasaran. Jakarta (ID): Kencana.

Silalahi, U. 2012. Metode Penelitian Sosial. Bandung (ID): PT Refika Aditama.

Solomon, M. 1992. Consumer Behaviour: Buying, Having, and Being. Boston (US): Allyn and Bacon.

Sugiyono. 2015. Metode Penelitian Pendidikan (Pendekatan Kuantitatif, Kualitatif, dan R\&D). Bandung: Alfabeta

Sumarwan, U. 2014. Perilaku Konsumen: Teori dan Penerapannya dalam Pemasaran. Ed ke-2. Bogor (ID): Ghalia Indonesia.

Suryani, A. J., R. Adiwinarti, \& E. Purbowati. 2012. Potongan komersial karkas dan edible portion pada sapi peranakan ongole (PO) yang diberi pakan jerami urinasi dan konsetrat dengan level yang berbeda. J Animal Agricultural. 1(1): 123-132.

Vijayanti, M. D., \& I. G. Yasa. 2016. Pengaruh lama usaha dan modal terhadap pendapatan dan efisiensi usaha pedagang sembako di pasar Kumbasari. E-Jurnal EP Unud. 5(12): 1539-1566.

Widiati, A. 2008. Pengaruh lama pelayuan, temperatur pembekuan dan bahan pengemas terhadap kualitas kimia daging sapi beku. J Ilmu dan Teknologi Hasil Ternak. 3(2): 39-49. 